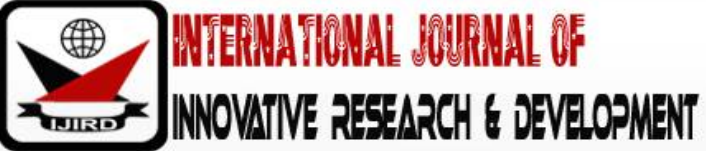

ISSN 2278-0211 (Online)

\section{The Rites of Passage as a Social Obligation for Sustainable Cultural Development: A Case Study of the Importance of the Rites across Cultures}

\author{
Bartholomew Johnson Sebbeh \\ Senior Lecturer, Department of Graphic Design Technology, \\ Takoradi Technical University, Ghana
}

\begin{abstract}
:
Throughout a person's life, there are stages of transitions that one passes through notably, birth, puberty (coming of age), marriage, and death. Significantly, each of these stages comes with various extensive rites and rituals that are performed and celebrated to usher the individual to his or her new status on the life ladder. Outdooring, naming, baptism are rites associated with birth whiles puberty and adolescent rite of varying nature (depending on the ethnic group), national service are ceremonies for people who come of age followed by marriage ceremonies including the payment of dowries, begging for hands, weddings ranging from indigenous (traditional), Christian marriage, Muslim marriage, etc., and death rites that encompasses the preparation of corpse, laying in state, pre-burial rites, burial rites and post-burial (funeral) rites. These rites are upheld by society to accentuate the importance attached to the individual roles assigned to the stages that the person is ushered into and thereabout. The ceremonies and celebrations come with respect and dignity even in post-burial rites. An individual who does not go through the rites and rituals are captured in the lenses of disdain and disapproval by the society yet many are those who do not see the need for the rite of passage even though societies across the world associate the rites with personal and social developments. In view of the importance that societies attach to the rites of passage, observations were made on some selected ethnic groups across cultures. The descriptive approach has been used to sample and describe the types of rites of passage performed in the selected cultures. This is to bring the importance of the rights to the fore to enable up and coming generations of various societies to recognize the need to uphold the rites as an obligation, safeguard the rites and rituals for their continuity and sustenance of the culture they have inherited from their ancestors to keep their culture alive.
\end{abstract}

Keywords: Rite of passage, rites, rituals, ancestors, culture, beliefs, transition, initiates, tradition

\section{Introduction}

There are landmark celebrations and ritual performances across cultures that characterize the movement of individuals from one state of social recognition to the other. These are done to accentuate the acceptance of the individual into the social class, accord him or her the respect and dignity associated with people who successfully go through such a transition. It is not only a matter of movement from one level on the social ladder but also a moment of assuming social responsibilities ascribed to the celebrant to make him or her discharge his role effectively, contribute positively to society and be acceptable in the society in which one finds him or herself.

In most societies where the culture of the people takes centre stage of societal development, individuals who disregard the rites and rituals bequeathed to them by their great ancestors, are considered to be miscreants and uncouth. They lack recognition by society and are not entrusted with precious heritage because it is presumed that such people would not be able to manage wealth the way society reveres and values it. Such people are treated with disdain and are perceived to be self-seekers and individualistic. This, as a matter of fact underscores the fact that societies especially, those in Africa place emphasis on communal values. This is in consonance with the observations expressed by (Gyekye, 2002) that communal values emanate from the values that expresses the appreciation of the worth and importance of the community, those values that underpin and guide the type of social relations, attitudes, and behaviour ought to exist between individuals who live together in a community, sharing, a social life and having a sense of common good. Gyekye cites examples of communal values that societies uphold as sharing, mutual aid, caring for others, interdependence, solidarity, reciprocal obligation, and social harmony.

Administering the rites of passage to members in their transitional period or stage and fulfilling the rites of passage by an individual, provides the framework of societal statuses, respect and appreciation. For this reason, in some societies especially in Ghana and Africa, grand durbars are organized to celebrate the events of transition observed by the people in the community. Such individuals who pass through the rites and the concomitant rituals are rewarded by way of 
gifts, presents and treasures that will prepare them to be capable to perform the responsibilities that go with the new status.

Everyone, whether black, white, Hispania or Eskimo is born into a unique society that has its culture as the guiding principle of how the individuals behave, act and carry themselves in the manner that is in congruous with the total aspirations of that society. Though culture differs from one society to the other, common elements such as beliefs, rites, skills, religion, values and norms cut across the tenets of cultures in the world. It is by the strict adherence of these and the display of lifestyles that an individual is identified as an Akan, Aborigine, Mende, Baule, Karan, Hotinttot, Pigmy, Zulu, American, Frenchman or woman, German, Indian, Finnish, Israeli, Russian just to mention but few. As people are born, from cradle to grave, they move through different statuses; these statuses are sometimes strongly institutionalized with accompanying rites.

The rites that form the initiation into an age set, and the transition from one grade to another, are usually accompanied by extensive rituals. Yet, there are people who do not seem to appreciate the need for these rites of passage especially in these modern times where enculturation is the order of the day. Because of this, many have lost the values and beliefs that identify them as members of the culture of the land of their birth. They thus become aliens in their own backyard and not being able to fit and contribute positively to the sustenance of the culture that was bequeathed to them by their forefathers. They do not take cognizance of the fact that the moments of the rites are period when the initiates are ascribed with social responsibilities that are collectively performed for the attainment of societal goals. If for any or no reason, an individual did not go through the rites and rituals in connection with the rites of passage of a particular culture, the individuals involved are considered half-baked, uncultured, irresponsible and uncouth. The people who do not go through the rites of passage especially in the African communities are often denied social support that characterizes and dignifies the celebrants. They are not the preferred choice when it comes to individual's responsibility to his kinship group and leadership roles in the cultural setup. The results of non-adherence to these cultural demands are the breeding of miscreants, teenage pregnancies, unpatriotic citizen, hard heartedness and people who do not have passion and compunction for societal underdevelopment.

It is for these reasons why it is prudent to espouse the importance of the rite of passage to enable people especially the youth and urban dwellers to uphold the observance of the rites of passage as a social obligation to the smooth transition at each of the person's life.

\section{Methodology}

This study is purely qualitative in nature in which the descriptive approach is used to sample and describe the types of rites of passage performed in the selected cultures to bring out the importance of the rites to enable members of various societies recognize the need for the rites. The descriptive research was also adopted to ensure that the issues involved are properly described as the rites, rituals and ceremonies in the rites of passage require more explanationthan exploration and experimentation. Moreover, in this research involving the rites of ethnic groups, the variables could not be manipulated because they follow laid down principles and cannot be altered like could be done in an experimental research. Using the descriptive research therefore led to accurate presentation of the events.

\section{Definitions of Rites of Passage}

A rite as described by Ampim (2003) is a fundamental act (or set of rituals) performed according to prescribed social rules and customs. Each of these rites is a key component that is a part of traditional African cultures.

Sloshed (2013) asserts that the concept of the 'Rite of Passage' is seen in all cultures. It's a universal mark indicative of transitioning from adolescence to adulthood in order to be accepted in a social group and across the world, rite of passage serves as a mean to isolate boys from men. Similarly, Schulz and Lavenda (2005) declare that rite of passage is a ritual that serves to mark the movement and transformation of an individual from one social position to another just as www.en.wikipedia.org describes it as a ritual event that marks a person's transition from one status to another. So, it is imperative to observe the rites of passage to ensure the smooth transition of the adolescents to adulthood.

In his opinion, Arthur (2010) claims that rites of passage are a ritual event that marks a person's progress from one status to another including ceremonies organized during puberty, coming of age, marriage and death. In drawing attention to the rites of passage, Brym and Lie (2007) describe it as the transition of the individual from one group to another to ensure his or her loyalty to the new group as an initiation rite which Van Gennep (1960), Schultz andLavenda (2005) call it rites of passage and consequently identifies three stages for the ceremony. These are separation from one's old status and identity - ritual rejection; degradation, disorientation, and stress - ritual death; and acceptance of the new group culture and status - ritual rebirth.

Grof (1996) declares that rites of passage are a category of rituals that mark the passage of a person through the life cycle, from one stage to another and from the point of view of Crossman (2014), a rite of passage is a ritual used to mark and accomplish the transition from one social status to another. Marriage ceremony for example is a rite of passage marking the transition from single to married. To Nanda and Warms (2012), rite of passage simply means a ritual that moves an individual from one social status to another.

In his assertion, Berry (1984) maintained that the various rites by means of which societies effect transitions in the life of an individual from one social identity to another include celebrations of crises in the life cycle is what is referred to as rites of passage and declared that all types of the rites of passage include an initial stage of separation, in which the individual is divorced from his familiar environment; a transitional stage, in which his old identity is destroyed and a new one created; and a final stage of incorporation, in which he is reintegrated into society in his new role. 
An elaborate explanation of rites of passage is given by Myerhoff, Camino, and Turner (1987) who say rites of passage mark distinctions in an otherwise continuous life course, celebrating and facilitating change and the disruption of standard social categories, while at the same time preserving them. The authors further explain that rites of passage are a category of rituals that mark the passage of a person through the life cycle, from one stage to another over time, from one role or social position to another, integrating the human and cultural experiences with biological destiny: birth, reproduction, and death. These ceremonies make the basic distinctions, observed in all groups, between young and old, male and female, living and dead.

Garrison (1998) claims that rites mark important transitional periods in a person's life such as weddings or parties. They strip a minor of their regular responsibilities and give them new ones. It is a ritual event that transcends children into adulthood. A rite or ritual is a repetition of occasions or forms, which has a symbolic signification (symbolic action). In the ordinary life, we find rituals as well as in psychopathological behaviours or in the sacred and religious area of life. A rite of passage (or initiation rite) is a ritual that marks a change in the person's social or sexual status, mainly related to puberty, child birth and menopause. The ritual is characterized by ceremonies and various tests. The rite of passage is a ceremony of recognition and public approval of the abandonment of an old identity and the acquisition of a new one.

The web site www.simplelivingworks.org notes that rites of passage are rituals or celebrations that mark the passage of a person through the life cycle, from one stage to another, from one role or social position to another. This definition is in line with the one provided by Schaefer and Lamm (1995) which state that rites of passage simply stand for the rituals that mark the symbolic transition from one social position to another just as the one provided by Nanda (1987) that claims the rites of passage mark the transition of an individual from one social status to another.

In an epitome, the researcher observed that rites of passage are transitional milestones in an individual's life that is marked with symbolic ritual ceremonies to publicly accept, ascribe, and usher, a person into a new paradigm of social status and responsibility.

\section{Characteristics of Rites of Passage}

People in all societies experience emotionally tense periods during the transitions between important phases of their lives. These are universally marked by ritual ceremonies O'Neil (2005). In addition, Campbell in www.earthpeople.org.au remarks that during these times of intense acceleration, many people are being called to take their places, change their paths, and for many, this is frightening.

On their part, Nanda and Warms (2012) write that male rites often involve an extended period during which boys are separated from the larger society. This emphasizes the importance of an individual's responsibility to his kinship group. Conway-Long, (1996) confirms the strenuous rites males go through by saying that one has to prove himself virile, successful in competition with other men daring heroic, and aggressive, 'proving their manhood' in formal rites, or more informally, on the street, in bars, or in warfare. This widespread need for males to publicly test and prove their manhood is what Gilmore (1990) in Nanda and Warms (2012) describes as the 'manhood puzzle' and also emphasizes that proving one's manhood helps him to fulfill his role as procreator, provider, and protector.

In the assertion of Heald (2010), rites of passage disconnect ritual moments from the normal flow of life, break the passage of time, representing it as a constant replay of opposed movements. Rather than inexorable process of growth and decay, the ritualization of the stages of life seems to speak to the discontinuity of personal experience and the oscillation of social life between contrasting moods and phases. Heald continues by saying that, these characteristics of rites of passage have been seen to make them most typical of traditional societies and repetitive social orders. Initiation during the rites of passage involves physical distresses which make the difference between the old life of the child and the new life of the adult more dramatic and lead to a greater acceptance of a new code of behaviour (Beidelman, 1971).

Before the ritual (rites of passage), the boys and girls have the public status of children. Afterward, they have the public status of grown men and women. Other rites of passage affect similar changes of status. Baptisms and other ceremonies around birth move the new child from the status of not-a-community member to membership in the community. For example, Quinceaner as mediate between the status of childhood and that of a young womanhood, eligible for dating. Marriage mediates between single and couple status. Funeral mediates between the living and the dead (Nanda and Warms, 2012).

Chodorow (1974) in Rosaldo and Lamphere (1975) believes there is more discontinuity in socialization for boys than females in that, boys are required to reject feminine qualities and identifications and be independent whereas the transition of girls into adult status is more of a continuation of their early life which is organized around and involved with family, primary and personal relationships and caring for others.

The features that are more prominent in all forms of the rites of passage, especially at coming of age are

- There is emphasis upon instruction in behavioural change that is appropriate to the status of adults.

- Instructions in dress, speech, behaviour and manners, and morality are given over a period of months.

- Instruction is first given at this time in matters of religion that have hitherto been kept secret, and the initiates may at this time be expected or required to commune with the supernatural, sometimes by means of revelatory trances induced by fasting, violent physical exertion, or the consumption of plant substances that produce hallucinations or otherwise alter the sensibilities.

- Male initiates are separated from their mothers and all females during the moments of the rites and the ritual events may dramatize the transition from a world of women and children to one that is ideally male.

- Initiation of females into adulthood consists of prescribed ceremonial events, given to all girls in a particular society and it is mostly performed at menarche and the initiate is sometimes isolated from society; sometimes 
she is the centre of attention. Some female rituals are elaborate and take years to perform; others however are performed with little ceremony (Lutkenhaus, Nancy, and Roscoe, 1995).

The process and details of initiation, as a matter of fact, differs from one society to the other but common features that permeate through the rites and rituals are songs, dance, masks, various tests and ordeals, tattooing, etc. that are used as verification and ritual symbolism yet their emphasis varies by society, some focus on bravery and toughness, and the others on spiritual aspects or practical education. Male rites are characterized by difficult, painful and dangerous tasks. The female transition from childhood is marked by a definite biological event which is menstruation. For the males, there is no single event that can be used to pinpoint entry into adulthood. Thus, men are forced to rely on culturally determined rituals to acknowledge their arrival into adulthood.

\section{Stages in the Rite of Passage}

There are three stages in the rites of passage namely, separation, transition, and re-aggregation. The stage of separation is explained by Van Gennep as the period that marks the individual's departure from the old position and from the normal time during which time the initiates disassociate themselves from the certain things they used to do before this new status. Transition which is the second stage of rites of passage is characterized by lack of role to play, ambiguity, and perceived danger. This is because the ritual 'passager' is neither in his or her old life nor in his or her new life yet. The transitional period which is also referred to as the 'liminal' period is when 'the individual is in the threshold, between and betwixt, neither here nor there, neither in nor out. The individual is subjected to a grinding-down process, after which he is rebuilt into something new. At the re-aggregation and the final stage of the rites of passage, the ritual 'passager' is reintroduced into society in his or her new position (Van Gennep, 1960).

Berry (1984), maintains that the stages of the rites of passage are flexible in application of 'systems,' and are still useful for the consideration of the way rites of passage change the participant's sense of identity. Berry points out that Separation which is the first stage in a rite of passage is characterized by loss of identity and is usually abrupt or violent in nature, ruptures, ties to self, family, or community.

Consenting with Van Gannep (1960), Berry also described the second stage in a rite of passage as the transition stage which is often called the liminal stage, and says 'it is an in-between time in which the participant has lost his old identity, but has not yet been fully re-incorporated into the community with a new identity.'This stage which Berry describes as 'a period of indeterminate identity, full of ambiguity and paradox', is mostly a period of confusion, testing, and education.

The individual experiences ritual dislocation of the self which may involve one or more of the following: dying symbolically, mutilation of self, losing name, language, breaking taboos, losing normal diet of foods, disguise, sex reversal, and behavioural reversals and is frequently involved in ordeals of a physical or mental nature such as beating, sleep deprivation, scarification, fasting, circumcision, ordeals and tests. However, the stage is often an educational transition as well as a revelation of religion, custom, skills, knowledge, and 'truth.'

The final stage of the process being incorporation is usually moving the participants out of isolation and back into the community with a new identity through a religious ceremony or communal meal amidst dancing and exchange of gifts. The whole community participates in the process centring on the new initiate or newly married pair. Emblems for the new status such as jewellery, new clothing, or new names are given to the participant. In most cases, the ritual involves individuals, immediate family, and the community at large.

For a better understanding, an elaboration is made with marriage as a modern rite of passage, which in most cases cannot occur until the pair is prepared to move out of their parent's house (separation). In the process the fiancé and fiancée often go through a period of 'engagement' after formal vows in which the pair is not supposed to live together. They even undergo sexually segregated rituals separately. For instance, during the bachelor party, the groom may engage in behavioural reversals and break taboos under the influence of intoxicants. In many religious practices, the would-be partners go through religious instructions and counselling (transition). The female partner discards her old name and adopts her husband's name (a new name). The actual ceremony that takes place between the two undergoing the rite of passage involves a giving to each other rings (exchange of gifts). Following the marriage ceremony, the community shows approval (incorporation) by offering wedding gifts, eating, and dancing (http://dictionary.reference.com).

In Joseph Campbell's Reflections on the Art of living edited by Diane K. Osbon, he noted that Rites of Passage, always involve the following three stages namely, separation, transition rites or the adventure and rites of incorporation. McKay and Brett (2008), also confirm this by pointing out that sociologists have identified three phases that constitute a proper rite of passage: separation, transition, and re-incorporation.

An initiate at the separation phase is separated in some way from his old life. In some ethnic groups, boys' heads are shaved and they are ritually bathed and/or tattooed. During the separation phase, part of the old life is snubbed for the initiate to prepare for the creation of a new identity. During the transition phase, the initiate finds himself at a 'crossroad'. He is not permitted to do the things young boys do but not yet fully initiated into his new status. He is taught the knowledge needed to become a full-fledged member of that group. In there-incorporation phase, the boy (the initiate) would now be recognized, honoured, and accepted by all tribe members as a man and allowed to participate in the activities and responsibilities that the status confers on him after passing various tests and proving himself worthy of the new status. During all the phases of the process, the men who have gone through the ritual themselves guide the young initiate on his journey. By controlling the rite of passage, the men decide when a boy becomes a man.

From the above discussion on the stages of rites of passage, it can be said that for most groups and societies including Akan, the rites of passage for young people usually include compassionate forms of separation, preparation, transition, and 
acknowledgment. For almost all the rites, they are based on life-affirming needs for acceptance, ceremony, and recognition.

\section{Discussions on the Functions of Rites of Passage}

Rites of passage is a mean through which people move ahead from a previous status and roles to a new level on the social ladder. The attributes of the new social status are wisdom and trust which people expect from the new 'entrant' to enable him embrace life in the new role with zeal as well as acceptance and support from the society.

Brown (1965) in Nanda and Warms (2012) gives the reasons why the rites of passage for girls are important as follows:

- The rites are a way of announcing a girl's status change, which is made necessary by the fact that she spent her adult life in the same place as she spent her childhood. Though the girl may continue to do the same kind of tasks she did as a child growing up, she now has to do them as a responsible adult. The rites are thus the means by which the girl publicly accepts her new legal role. Where the girl moves to her husband's home after marriage, this move itself signals the change from childhood to adulthood.

- $\quad$ The rites are a way of teaching the girls what they will have to know as adults. For example, the Bemba women explain their elaborate girl's initiation rite - the Chisungu by saying that they 'make the girls clever'

- In societies where females play a central role in subsistence, the rites are performed in order to assure the girl and others of her competence and to impress upon her the importance of her adult role.

Rites of passage have functions at the individual level and at the collective level. At the individual level, they help us to fight against and to structure our existential anxiety; they facilitate the integration of the individual into the group and his self-identification. The rites indicate the road. They give models and keys for approaching the coming stages of life. They also offer the support of the community that recognizes the difficulty of these passages and propose ritualized and structuring practices. And they reconnect each of us with our lineage and the heritage of our ancestors.

At the collective level, they serve to strengthen beliefs, values, and ideologies (in the religious, political, social, business fields) and to maintain hierarchical order; and so on. They clarify the position of each member of the community. The rites of passage allow binding the individual with the group and in the same time structuring the individual's life in precise stages that give him a reassuring perception of his temporality and his mortality.

A rite of passage is designed to give experiences, to assure the initiates to come out of the experience with a new and empowering story that helps them take responsibility for the decisions that set the course of their future. It assists the initiates to create the story of who they are and the kind of life they want to build based on the exploration of their own personal values. Rites of passage also help the individuals to find the story that connects them to their community.

Rites of passage according to the African holocaust website (2014), play a central role in African socialization, demarking the different stages in an individual's development, as well as that person's relationship and role to the broader community. The African holocaust website (2014) is of the view that as a result of the rites of passage, society is able to preserve the ongoing community as a symbol of collective immortality and permanence as it provides a clear and guided means for transition from one life stage and sphere of responsibility to another. The rites of passage confirm the hierarchies of values of the community and offers the individual with an ideal sequence of personal development which he or she can look forward to such that upon reaching each stage, he or she is able to assess his or her maturation against a collective standard.

The web site www.africanholocaust.net goes on to say that the initiation rites involved the link of the individual to the community and the community to the broader and more potent spirit world. Initiation rites are proven to be a necessary extension of many communities and are as necessary and natural as the arms and legs are natural and necessary extension of the human body. Rites of passage provide the African with the foundation of his or her being, that is, his or her identity. Consequently, the sexual identity and the roles of gender identity are properly set out through the rites of passage so much so that the males and females are prepared for their duties in the community as men and women prepared for their distinct responsibilities without confusion.

'Among the Kurla of Kenya and Tanzania for example, life for both men and women is said not to begin and end with their birth and death but rather to begin in early puberty when they are circumcised and to culminate in dramatic rituals of eldership, which celebrate the achievement of a full life course, of successful fertility, and of wealth as evidence in the growth of the homestead herd' (Heald, 2010).

An observation made in http://www.simplelivingworks.org/ indicated that the rites of passage served at least four functions as explained below:

\subsection{Safe Passage}

Rites of passage integrate biological reality (birth, reproduction, and death) with cultural and religious experience. Passages are anxiety-producing life crises. The rites not only 'give permission for' or legitimate - the anxiety, but they allay it by giving meaning to the experience. They make the 'passage' from one life stage to another safe and clear.

\subsection{Moments of Learning}

Although some rites of passage occurred at great moments of anxiety (life crisis), all provided an atmosphere in which learning could take place. By calling attention to the particular life change, rites of passage may have increased anxiety, but did so in a context where important learning occurred that assisted in the transition. For example, acknowledging the reality of death in a funeral or memorial service may increase anxieties already being experienced. But that ritual acknowledgment may also aid in accepting life without the one who has died. 


\subsection{Connection to Community}

The celebration of rites of passage connects the individuals to a community. The physiological fact is that one is born and dies alone, unique and separate. But each one is also a member of a community, a group that has particular values and understandings of life. Rites of passage connect the individual experience to the understandings of the group in such a way as to give meaning to that experience. While Christian rites of infant baptism, christening, and dedication are performed for different reasons, what they have in common is that they celebrate the linkage of the individual to a group.

\subsection{Transformation Experiences}

Rites do not only help to facilitate the passage from one stage to another, but they actually shape and manipulate biological imperatives as well. The message from ancient societies is that women and men are not simply born, nor do they merely procreate and die; what they are is in part what they are 'made' through rites of passage. In some societies, girls 'became' women when they went through puberty rites, whether or not they had begun to menstruate; and adolescent boys 'became' men when they went on the hunt or were circumcised whether or not they had gone through puberty.

As humans, we dwell in an equivocal world, for we belong to both nature and culture, it is through rites of passage that we are able to contemplate, to formulate and reformulate our ambivalent condition of animal and human (Meyerhoff, Camino, and Edith, 2001). Accordingly, the ceremonies in the rites of passage will make the individual aware of the social role he or she is expected to perform at a particular point on the transitional ladder.

Rites of passage mark the various milestones in the life chain and is celebrated to facilitate the expected change and social standards for the 'new entrants' to consolidate the gains made in the social setup and preserve them. Psychologically, everybody is born and dies alone differently. Though we are born separately and bound to die separately, we acknowledge the values that are unique as a group and ensure continuity in all spheres of our life such as those that define our birth, aging, and death which gives renewed assurance that life is meaningful. During the performance of these life-crisis rituals, societies inscribe their designs both literally and figuratively upon the initiate, and in doing so, life's paradoxes are proclaimed, contemplated, and dramatized.

The struggle between nature and culture is evidenced in Bali, where before a young man or woman may marry, he or she undergoes a tooth-filing ceremony, in which the canine tooth, the mark of the beast, is smoothed so that the smile is less reminiscent of an animal's snarl. The theme of disruption and continuity is enacted in certain African societies, where, as Victor Turner has described, an initiate undergoing male puberty ceremonies ingests a powder ground from the burned foreskins of previous initiates, thereby incorporating into his body the vitality and power of his forebears. Rites of transition performed for divine royalty-birth, marriage, procreation, and death-are rites performed for the perpetuity of the kingdom as a whole, and in certain cultures a king has to be killed annually in order to rejuvenate and ensure the fertility of the land. Moreover, certain rites of passage, such as healing rituals, may serve to resolve social problems and to perpetuate the social order directly as well as indirectly because they treat not only the sick or diseased person but also the entire society.

Gamst and Norbeck (1976) emphasize that rituals and beliefs support social structure and institutionalized customs such that in the family and other social units, the scheme of social stratification, moral or ethical codes, institutions such as marriage, symbolically express customs and social relationships and place upon the young a stamp of sacred approval. Rituals and beliefs are held to fortify the individual element expressed and also the whole.

The authors maintain that group ceremonies assist in promoting social cohesion by jointly expressing and reinforcing or teaching the values of the society and stress that group participation in the kind of activities involved presumably intensified social cohesion, but religious rites are held to be particularly effective because of the formal seal of sanctification which they give to the cultural norms they express. Society depends for its existence upon common social sentiments, and ritual acts are symbolic expressions of these sentiments which reaffirm them and maintain their intensity. The Kaguru in the east of Africa recognize initiations as necessary in order to convert irresponsible, immature minors into morally responsible adults. The Kaguru male initiation consists of circumcision and moral instruction through which the initiates learn how to conduct themselves as adults (Beidelman, 1971)

Male rites of passage have important psychological and social functions. They reinforce the social order by dramatizing cultural values in a public context. They express and affirm male relationships, male solidarity, and, sometimes, male dominance; they publicly validate a change of status from childhood to adulthood; and the cultural knowledge necessary to being a responsible adult male in the society. Male rites of passage often involve an extended period during which boys are separated from the larger society, which emphasizes the importance of an individual's responsibility to his kinship group as well as the community. These rites often include painful practices such as scarification or circumcision that symbolize the formal transition from child to adult. Such rites may also include difficult and dangerous tasks, such as killing a large animal, which test a boy's preparation for the obligations of male adult (Hart, 1967). Hart further explained that female rites of passage are more widespread than male rites, although generally less spectacular and intense.

Varying explanations are given to female initiation rites especially in societies where matrilineal system of inheritance is practiced and the young girl continues her childhood task in her mother's home, an important function of the rites is to publicly announce the change in her status because from now on, the expectation is that she will perform her tasks as a responsible adult. She is taught what she needs to know to be an effective adult. Furthermore, the rites of passage also channel sexuality into adult reproduction, and in some rituals, the rites emphasize the connection between beauty, sexuality, and power. In most cases, girls are motivated to bear and nurture children, strengthen their fortitude, and provide them with the capacity for hard work necessary to assist their husbands in gathering wealth. 
Going through the rites of passage, a liminal space is created for boys and girls to gain a meaningful and unforgettable experience that offer them an opportunity to grow and expand their call to become what they truly represent. The rites therefore serve as means to maturity to either manhood or womanhood. The rites also perform some social and psychological functions such as

- Separating boys from their fathers to make them face the world with confidence

- Separate boys from their mothers to make them (boys) manifest masculinity in all aspects of their lives and to redirect their relationship or association with their mothers.

- Assuring the young of the care and compassion the older generation has for them.

- Exposing them to handle extreme provocation with comportment and to develop a passion for life.

- To help the young to eschew timidity, foster self-direction and to build a connection with the community as a responsible adult.

Rites of passage are performed to instil confidence and promote emotional intelligence in the adolescents. Lott (2014) maintains that the rites of passage for adolescents are not just a male issue but a need for both males and females. He says men may join gangs, but the violence girls do to themselves in adolescence is self-harming and self-starving which is equally problematic. Lott (2014) goes on to say that there may be no secular rites of passage within families for girls to mark their first menses, or for boys to mark their physical maturity yet this idea of making the passage from child to adult has appeared in all cultures at all times in history.

Sisson (2012) acknowledges that rites of passage exist in order to consolidate social ties, establish roles, and give members of a group a sense of purpose and placement. Everyone needs a stake in a tribe, and rites of passage help provide that by establishing and formalizing the roles at various life-stages, make social ties stronger and easier to establish because members of the society are able to cohere, cooperate, and work together and feel intrinsic bonds with family members.

Stauber and Ronconi (2013) lament that the world today is changing rapidly as the economy is very fragile. 'We are at war. Terrorism is a national threat. Our planet is in peril with the spectre of pollution and global warming looming.' The anxiety that goes with this kind of universal upheaval can be enhanced for many by participating in the ceremony and rituals and giving recognition to the rites of passage of our lives. This therefore is a need that has to be met.

Grimes in Stauber and Ronconi (2013) holds the view that by authentically honouring ceremonies, which aid in marking the major milestones that herald the transitions from one status group into another within our society, the confusion will be reduced and facilitate the changes. An aspect of the rites that is important is the recognition given by the community which provides a sense of the variety of life, belonging and being welcomed into a new status in the group.

Nanda and Warms (2012) observed that male rites of passage were identified to perform some important psychological and social functions as listed below:

- They reinforce the social order by dramatizing cultural values in a public context. By taking the child out of the home, the initiation rite emphasizes the importance of citizenship.

- They express and affirm male relationships, male solidarity, and sometimes male dominance

- They publicly validate a change of social status from child to adult

- They transmit the cultural knowledge necessary to being a responsible adult in the society.

Hart (1967) observes that male initiation rites can be seen as bridging the gap where discontinuities exist between early childhood socialization and the requirement of an adult masculine role. In view of that it is also necessary to ensure the development of an adequate male role. Hart insists that initiation rites perform educational functions that are equivalent to the formal classroom teaching and learning received by children.

From the submissions, it could be noticed that societies assign specific roles to individuals at different points or stages in their lives. These individuals are expected to prove that they are capable and ready to take up the tasks and challenges that come with them. In this regard, most of the societies organize and take the expectant individuals through various public rituals and ceremonies to officially accept them as members with new social identity. In all cultures, the roles and expectations of individuals change at different stages in life and the individual must learn what is necessary for these new roles. These rites help people to understand their new roles in society. They also help others to learn to treat people in the new ways with respect and dignity they deserve after they experience certain rites of passage. The researcher also noted that these transitional rites are not the preserve of a particular society or community but cut across societies in the world. Although the rituals and ceremonies involved in the particular rite of passage may differ in character and style, the impact remains the same.

\section{Ritualism in Rites of Passage}

In considering what ritualism refers to in the observance of rites of passage, Penner (2014) declares that a ritual is the performance of ceremonial acts prescribed by tradition or by sacerdotal decree. Ritual is a specific observable mode of behaviour exhibited by all known societies. Rituals are mediums of defining or describing humans. Nanda and Warm (2012) add that a ritual is a ceremonial act or repeated stylized gesture used for specific occasions involving the use of religious symbols.

On his part, Norbeck (2014) elucidates that ritual ceremonies involved in social transformation of the young ones, include all the life-cycle ceremonies as they involve social transitions for the subjects of the ritual and also for other persons. A man or woman, who dies, for example, assumes a new social role as a spirit that may be socially important to the living, the bereaved spouse becomes a widow or widower, and the children have an unnamed but changed status as lacking one parent. 
From the point of view of Nanda (1987), in almost all societies, transitions in social status from conception, birth, puberty, marriage, and death are surrounded by religious ritual. Consenting to the stages propounded by Gannep (1960), Nanda writes that the individual is removed from his old group or status during the separation phase and the ritual involved is having head shaved, or casting off one's old name. The ritual of this phase symbolizes the loss of old status or personality. For the transition phase, the individual is cut off from old status and not as yet been incorporated into the new status. The individual is treated as sacred in the recognition of the power and danger of the in-between position. The rituals and symbols associated with the incorporation phase are often of rebirth. To this end, Nanda describes ritual as a patterned act that involves the manipulation of religious symbols.

\section{Discussions on the Rites of Passage across Selected Cultures}

Every society the world over possesses a form of culture that is peculiar to its existence and there are landmark events that characterize the transitional processes that set the various dichotomies between the roles of individuals in progression with regards to age and other factors that lead to social acceptance. From time immemorial, rites of passage are ceremonial events that have been marked in all known societies at the movement from one social or religious status to another. The discussions however are based on rites of a cross section of societies in the world with greatest attention to the most common types of rites, and discusses their purposes from the viewpoints of the people who observe the rites, and the socio-cultural and psychological significance attributed to its adherence.

Garrison (1998) summarizes the rites into five components comprising birth, adulthood, marriage, eldership, and ancestorship. Garrison justifies these five rites by referring to the integrated initiation system that has given indigenous African cultures the stability and longevity to provide a model of consistency and inter-generational unity. These are mechanisms to curb misunderstandings among age brackets and the ill feeling against women, children, and elders, a problem that is commonplace in the western world but not prevalent among the indigenous African society. Garrison concluded by saying, 'these African cultures were not 'perfect' as all human societies have problems, but they do provide a viable example in the modern world of how to solve social conflicts and contradictions and give individuals the societal support to discover and fulfill their life mission and unique contribution.'

Whilst Garrison named five rites, Stauber and Ronconi (2013) on their part, identify four major rites of passages in our lives as birth, coming of age, marriage and death. They explain that marriage and birth are passages of integration, coming of age is a passage of initiation, and death is a passage of separation. These landmark transitions are characterized by change in status where adolescents exit the world of childhood, married persons leaving the single life, birth that signals the beginning of parenthood and the life cycle is completed by the rites performed for the individual at death. Nanda and Warms (2012) agrees to Stauber \& Ronconi's submissions by saying rites of passage are public events that mark the transition from one social status to another which almost always mark birth, puberty, marriage, and death and may include many other transitions as well.

In the early days of birth especially on the eighth day, the rite of circumcision is practiced, as a way of marking the transition from childhood to adulthood. Very commonly, there is a period of separation from a normal life of the community, and certain ritual prohibitions have to be observed. Rites of this nature have been called rites de passage, or transitional rituals (Beattie, 1992).

Research has revealed that it is an undisputed fact that every society commemorates rites of passage as a way of initiating its members into responsible positions in the social fabric. The initiations span the time from birth to death and are heralded with various rituals that graduates the celebrants into their new statuses. The rites and their associated rituals may begin immediately after birth in some cultures including the Akan communities in Ghana and the Ivory Coast (Cote d'Ivoire) in Africa. In some societies, it starts from the eighth day after the birth of the child when naming rites are performed to give the child an identity. Naming as a rite of passage cut across cultures as each person born in the world is identified with a name. It is the rituals involved that make the difference but the social and religious importance remains the same.

All over the world, rites of passage are performed for people in their adolescence and accounts for the development of a stable adult personality. In Western culture, such rites as the Bar Mitzvah, Sweet 16 parties, and Quinceañera are the most familiar. In tribal cultures, coming of age ceremonies are, in many cases, much more elaborate and can be truly terrifying.

Schaefer and Lamm (1995) claim that as traditional rites of passage into adulthood, the Kota people in the Congo who view the colour blue as the colour of death, paint the body of the male adolescent blue to symbolize the death of childhood and consequently journey into the bush to complete the transformational ritual into adulthood. So, male adolescents after going through this bodily painting of blue and the concomitant ritual, attain the status of men.

Some rites of passages are Quinceneras, Rumspringa, Female Mutilation, various women initiation rites in Africa and Prom especially in the United States. These rites of passage are essential to some cultures, religions and people. In some places it is mandatory to go through a rite of passage to be respected or to be on the same level with an adult.

Among the Akans of Ghana, girls who have come of age are ushered into eight-day adolescent rites at menarche popularly known as 'bragors'. In much the same way, the Krobos who are also an ethnic group in Ghana organizes a similar rite called 'Dipo' for the young girls who come of age whereas the Ga take their girls through 'Otofo' to prepare them into responsible womanhood. The ceremony involves shaving, bathing, and exposure of the girls' breast. These rites are performed to signal to the public that the girls are ready for marriage. During the period, the girl or girls undergo various training under the tutelage of some elderly women. 


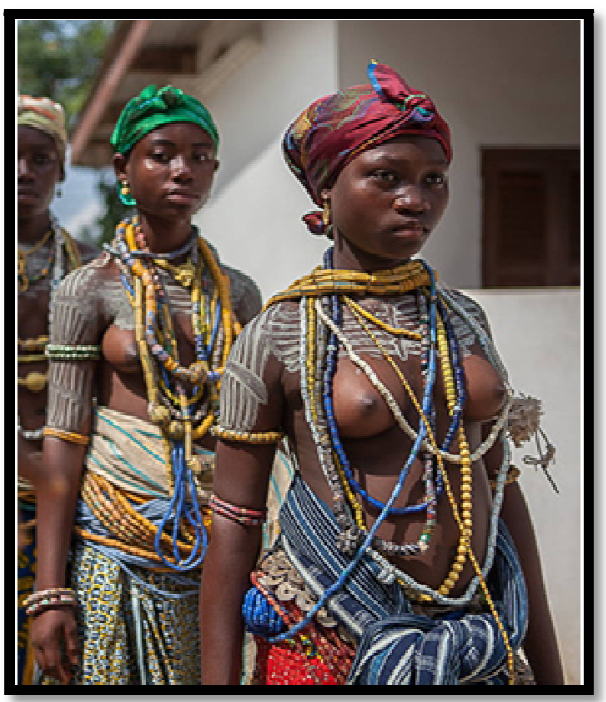

Figure 1: Krobo (Ghana) Girls Decorated with Expensive Beads in 'Dipo' Ceremony

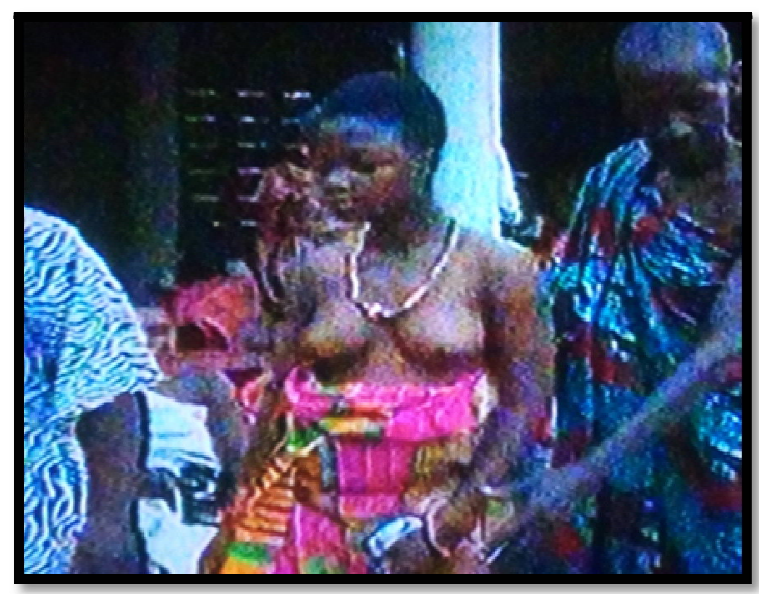

Figure 2: Akan Girl Dressed in Rich Ghanaian Kente Cloth Celebrating Puberty Ceremony

In America, military service that compels the recruits to leave their families behind and move to new places is considered a period of separation in the rite of passage of the young high school leavers who are forced to leave behind the clothing, activities, and even the hair that marked their identity in civilian life. In the military, recruits are forced to dress and act alike and are subjected to a grinding-down process after which they are rebuilt into something new. Other familiar rites of passage in the United States, according to Schultz and Lavender (2005), include high school graduation and the significant ceremonies associated with the twenty-first birthdays which are understood as movements from one kind of person to another (p.167). While the Americans observe the twenty-first Birthday as a rite of passage, for the Latinas and Mexicans, they observe Quinceanera which marks the $15^{\text {th }}$ Birthday as an important rite of passage celebrated to usher the female into womanhood.

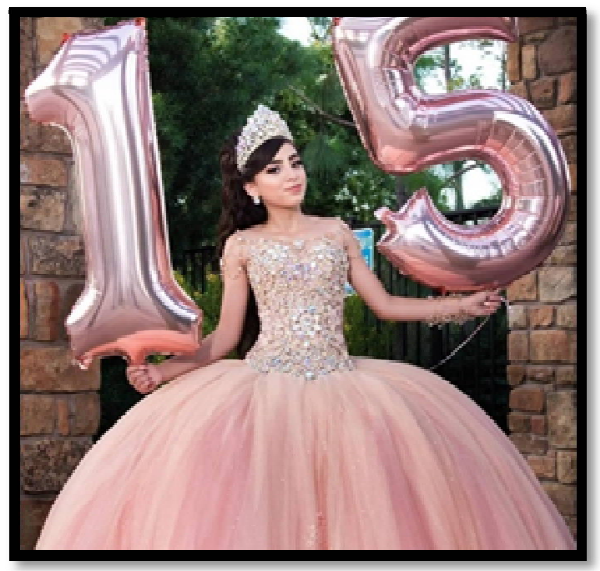

Figure 3: Girl at Age 15 Celebrating Quince Near a Image Credit 
Initiation ceremonies such as baptism, confirmation and or bat mitzvah are considered important rites of passage for persons of their respective religions. Bat mitzvah is a ceremony and celebration that is held for a Jewish girl between the ages of twelve and fourteen at which she accepts the religious responsibilities of an adult (Oxford Advanced Learner's Compass, 2005)

In the Hamar territory of Ethiopia, men who come of age are taken through cow jumping exercise in which only castrated male cattle and cows are used before a man is permitted to marry. The man-to-be, must 'jump over the cattle' four times to be successful. He does this jumping naked with a few cords bound across his chest as seen in the plates below. This is symbolic of the childhood he is about to leave behind him. Having completed this test, the young man then joins the ranks of the 'maza', men that have recently passed the same test and spending the next few months of their lives supervising these events in villages (Frater, 2009).

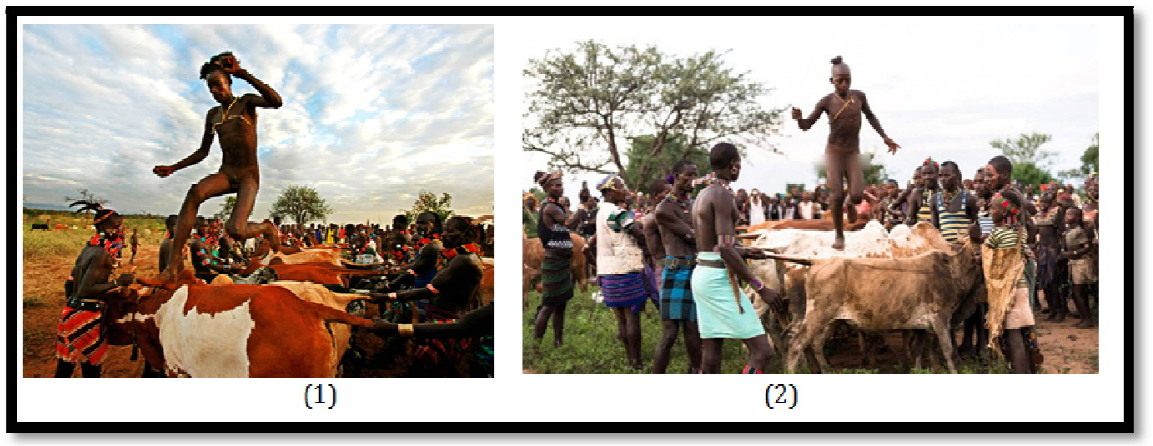

Figure 4

Image Credit:

1. http://www.adventureabyssinia.com/festival-cultures/cultural-ceremonies/bull-jumping-ceremony-of-thehamar-tribe/

2. http://biapic.com/ethiopian-coming-age-tradition-hamar-cow-jumping/

Whiles males in Hamar in Ethiopia are jumping cows, their Mursi female counterparts in the other part of the country are taken through 'mouth widening' rituals. When a Mursi girl has reached puberty, to mark the change of identity from girl to woman, she becomes a 'Bansanai'. To mark this change, teenagers begin the process of stretching their lower lip. They do this by cutting acentimetre-long incision in their lower lip and plugging it with a wooden peg (United Television, 2014).

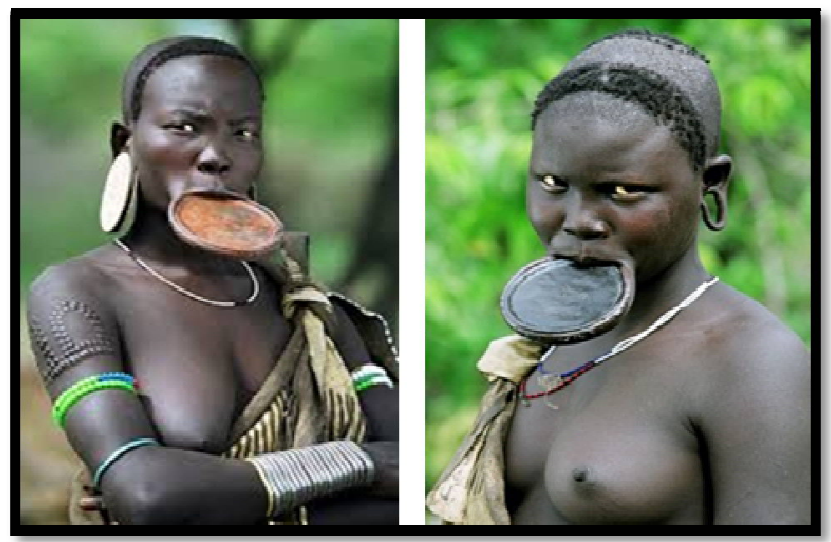

Figure 5: Picture credit: Stephanie Parker http://www.bigworldsmallpockets.com/

February 16, 2018

In Canada, boys in the Algonquin Indian Tribe of Quebec used to be caged and sent to a secluded area where they were given an intoxicating medicine called Wysoccan an extremely dangerous hallucinogen which is said to be 100 times more powerful than lysergic acid diethylamide (LSD). The ritual was meant to force any memories of being a child out of the mind of the boy. Boys who showed recognition towards their childhood after returning to the village were then taken back and given a second dose and forced to attempt to cheat death a second time (Frater, 2009).

Men who live on the Pentecost Island in Vanuatu go through land diving to prove they have come of age. Land diving is both a harvest ritual and a rite of passage amongst the ethnic groups of the small pacific island of Vanuatu and has now become a tourist phenomenon. The ritual involves men climbing a rickety of 98-foot-tall (30-meter) tower, tie vines to their ankles and dive to the ground, falling at speeds around $45 \mathrm{mph}(72 \mathrm{kph})$. When a dive goes correctly, the person gets close enough to touch his shoulders or his head to the earth. These vines are not elastic and any miscalculation in vine length could lead to broken legs, cracked skulls, or even death. After boys have been circumcised at about age 7 or 8 , they begin to participate, with permission to jump from a shorter tower. As a boy makes his first dive, his mother holds an item 
that represents his childhood. When he jumps, she throws the item away. Divers also refrain from sex the day before they jump - legend says it will cause the jump to go badly.According to Sanders (2018) 'The Land Diving ritual has stood its time for 15 centuries. It serves two purposes: A sacrifice to the gods for the yearly harvest, and as a rite of initiation into adulthood'.

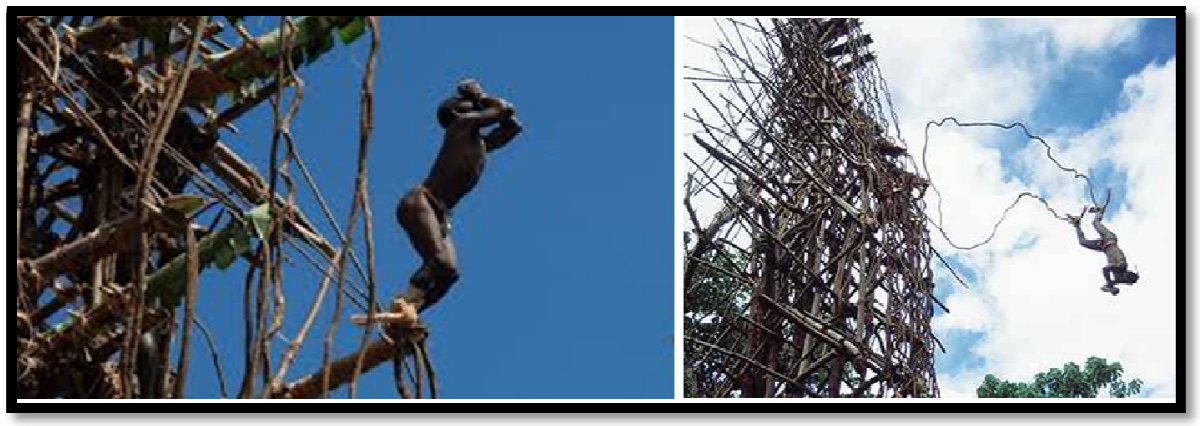

Figure 6: Image Credit: James Sanders (Oct 20, 2018) -

Landdivers during Rite of Passage in Vanuatu

Elsewhere among the Australian Aborigines, an adolescent boy becomes a man when he goes on a trek across the outback for up to six months together with his father, his grandfather and the local spiritual leader. This walkabout is a way to show the boy what it means to be an Aborigine by bonding with the land of his ancestors. They would follow the trails their forefathers took. Picking out their heroic acts, the boys would mimic them to show how much of a man they are (Sloshed, 2013).

To become a man capable of hunting in the Amazon jungle in Brazil, one has to participate in four (4) Matis Trials. In the first instance, bitter poison is put into the eyes for the purpose of boosting the initiate's vision and intelligence. The second face of the initiation involves beating and whipping followed by the injection of a small poisonous frog by burning a portion of the skin and inoculating it with the toxin using wood as needle. This is done in the third stage for an increased strength and endurance after going through reeling sensation, forceful discharging of the bowels, and intense vomiting. Having been successful in the trials they are treated to performing them before every future hunt they partake in (Frater, 2009).

For the Tukuna people of Northwestern Amazon, their initiation rites into womanhood known as Festa das Mocas Novas, begins with the first occurrence of menstruation. The woman (initiate) spends the next four (4) to twelve (12) weeks after menstruation in a secluded small chamber built purposely for initiation within the family dwellings. During this period, the initiate is thought to be in the underworld and in ever-increasing danger from demons known as the 'Noo'. To climax the initiation rites, guests arrive with some wearing masks to mimic incarnations of the Noo. For more than two days the initiate remains in the secluded chamber with her body painted with black genipap dye to protect her from the Noo. She therefore emerges from her chamber in the morning of the third day surrounded and given protection by her relatives and ushered into the festivities amidst dances till dawn. A shaman then gives a firebrand to the initiate to throw at the Noo to break its power. If that is done the female of Tukuna is safely entered into womanhood.

Boys and girls in Okiek Tribe, Kenya, whose ages are 14 to 16 go through similar rite of passage ceremony although the genders are initiated separately. Ceremonially, the initiates are first circumcised or excised. After this, they live in seclusion from adults of the opposite sex for four (4) to twenty (24) weeks. They paint themselves with white clay and charcoal in order to appear as wild creatures (cemaasiisyek). Certain secret knowledge is imparted by same-sex elders. The most important knowledge concerns the cemaasiit - a mythical beast that haunts the initiates during their time in seclusion. At night its roar can be heard, and the initiation is complete when each youth has seen and held the instrument used for producing the roar and then produced the roar themselves (McKay, 2010).

Young men in the Satere-MaweTrive in the Amazon tribe have to endure the painful bites of hundreds of bullet ants which is said to be about 20 times the sting of the wasp to become men. When the boys wake up, the tribesmen put their hands into mittens of the bullet ants gathered and submerged into a solution and dance for about 10 minutes. The ant's sting prevents the body from protecting itself from pain and that the body start to shake. Although the pain can last up to about 24 hours, to prove their bravery and manhood, most of the men repeat this ritual.

Elsewhere in Papua New Guinea boys in the Sambia tribe as part of their initiation, are separated from their maternal figure and all females and placed in a special house where they live with males for the next ten years. At the initial stage, the skin of the uninitiated boy is pierced to clear any external contamination from women and undergo an intense mandatory nose bleeding. As a way of cleansing their body internally, they are forced to consume sugar cane to stimulate vomiting and defecation. Having been cleared of contamination, they are required to ingest semen, which is considered vital to ignite masculine growth, and strength. During the initiation, they are made aware of the impurities women bring and how they may harm them and taught purification techniques at the fifth stage because once they get married and heterosexual, they must purify themselves of any contamination from their wife. They engage in heavy nose bleeding following the menstruation of their wives. As part of the initiation, the boys are taken to the forest, pointed towards a structure facing a tree, and asked to remove pubic hair handed to one man who places the hairs in the trunk of a pandanus tree. The men tell them story about the Harp of the Jew and its significance and warn them not to be promiscuous in their heterosexual relationship otherwise they will be killed (Frater, 2008). 
Similarly, Nigerian girls in Okirika tribe have to go through the 'Iria' rites to free themselves first from their romantic attachments with the water spirits before they can be considered marriageable. From their fourteenth to sixteenth year, the girls are taken into fatting rooms and richly fed to make their bodies 'come out'. Whiles there, the elderly women teach them how to sing Iria songs. To make their freedom possible, the girls come together at the river and sing the songs learnt on successive dawns. On the final day, the girls go back to the riverbank with the expectation that the water spirit will attempt to seize them. To prevent the seizure, a senior member of the Owuper society often referred to as 'Osokolo' strikes the girls with sticks to drive them back to the village to ensure their safety and future fertility.

An Aborigine young boy in Mardudjara, Australia is led into seclusion by his tribal elders when he comes of age. There, they lie down to surround the boy facing away from fire with one of them sitting on the boy's chest. In the process, one of the elders pulls and twists the boy's foreskin and slice it off. They then make the boy kneel upon a shield over a lowlit fire and make him eat the meat which is his own foreskin by swallowing it. His success means that he has eaten his own boy and has now become a man. When the circumcision heals, the young man will go through a sub incision. A cut is made underneath his penis, sometimes to the scrotum and made to stand above a fire for the blood to drip into it and purify it. Men do this to sympathize with their female counterparts (Frater, 2009).

Male members of the Awa tribe in New Guinea in their quest to move from childhood to adulthood, as a prelude, are subjected to whipping just their counterpart in the Matis trial in the Amazon jungle in Brazil. The Awa boys go through whipping with sticks and prickly branches for two or three days. They endure the whipping for their past misdeeds and also in honour of the fallen tribesmen who lost their lives in warfare. Their beating is followed by jabbing sharp sticks into their nostrils until the boy's bleed profusely, then gag and vomit after a five-foot length of vine is forced into their throat. Deep cut is made on the boys' genitals by the tribesmen and finally release to bleed severely into a stream whiles onlooker make mockery and poke at the cut to make them bleed plentifully (Feldman, 1996).

The discussions made so far are indicative of the fact that societies the world over have various forms of rituals that females and male are taken through to confirm their transition from childhood to adulthood. One thing that runs through the rites is that men are taken through more strenuous activities than women to prove their manliness in most cultures.

In most societies across the world, the focus of coming-of-age and its concomitant rituals is on the males other than females with the fear that if care is not taken, boys will not live up to the expectation of being men. More so, in most traditions, men are accorded higher status and that their transition into adulthood is given more prominence.

Significantly, the rituals of boys seem atrocious as some of them have to endure whipping, public circumcision, dive from higher height, standing above fire with others subjecting themselves to be bitten by hundreds of ants among other activities. However, some of the rituals are less fearsome but have the same value as the rigorous ones yet they are obligatory in their respective societies.

\section{Conclusions}

- It is an undisputable fact that everybody who comes into this world, if for nothing at all, experiences at least two rites of passage namely, the birth and death rites. The birth rites serve as an occasion in which everyone obtained his or her initial naming that occurs mostly on or after the seventh day. This event is regarded as a public announcement of the child's birth-right as a member of the society in which he or she was born. Similarly, members of societies across the world go through transitional rites performed to usher them into the community of the dead.

- $\quad$ Every society has occasions and event set aside for its members to be admitted into the social structure to make them acceptable and be seen as mature and ready for certain social roles and to assigned the roles after going through the necessary rites and rituals.

- The Rites and rituals of Passage are important milestones for the beginnings and endings of lives of every individual that should not be overlooked. Events such as weddings, naming/christenings, swearing ins, baptism, confirmations, graduations, swearing- ins, coronations, enstoolments, enskinments, birthdays, ordinations, etc. serve as beginnings in human live and the events like preparation of corpse, observation of wake keepings, pouring of libation for the burial of the dead body, Christian burial services among others are by tradition ceremonies rites and rituals that intersperse the death of an individual.

- People, especially those who live in the urban communities and not go through the rites of passage as enshrined in their culture are regarded as social misfit and are considered as uncultured and are looked down upon by their traditional folks who see the rites as a qualification to social recognition.

- The rites of passage bring about social change in the life of a person irrespective of race, colour, or ethnic grouping. The essence of the rite remains the same everywhere across the cultural divides for, it is done to commemorate the social development of the individual as he or she moves on the social ladder.

- Although most cultures give recognition to the importance of the rites of passage, the mode of celebration vary from society to society. Whereas some groups prefer to commemorate the coming of age with birthday parties, others organize a puberty rite that has a wider participation of members of the community. In some cultures, the entry from young adult to full adulthood is commemorated with gracious events especially with females while others go through rigorous and deadly rituals and activities (on the part of males) to the test their endurance level that will earn him the respect of his peers and the community at large.

- The rites of passage are significant events that are performed for the individual ready to move from one group to the other on the social hierarchy. The rites are thus used to signify the change of one's status in society and to ascribe social responsibilities that commensurate his or her social standing. 


\section{Recommendations}

- Societies and groups in the world should not renege on their effort at ensuring that its members adhere and submit themselves to the rites of passage bequeathed to them by their great grandparents as this gives the assurance that there are people to whom the mantle of managing the development of the society can be handed.

- Interests in the performance and participation in the rites and rituals associated with the rites of passage should be whipped up among the members in the communities by eliminating some of the outmoded, scary and bizarre customs and activities that draw people away from the rites. This can be achieved by fashioning out activities that will motivate members especially those who may come of age to avail and offer themselves for the ceremonies.

- Issues of Rites of passage should be inculcated into the social and cultural studies curriculum especially at the elementary and Junior High School levels to assist students learn about their cultural rites, their responsibility to the sustenance of the rites in society, and benefits to be derived from the rites. At school they could be taught the importance of the rites, skills and tasks one is expected to acquire to accomplish the feeling of competency. That will make the students become obliged and enthusiastic to participate in these all-important rites of passage that will earn them the recognition of their society. All said and done, it will provide teenagers with knowledge on the departure from childhood years and help them set expectations for their behaviour.

- Those who do not know about the significance of rites of passage and the concomitant rituals should now understand that the rites of passage are important and the rituals by all standards are meaningful. They ought to know that the rites of passage, rituals, and ceremonies are important in the lives of everybody and that every ceremony and activity is held for a reason which is all about the preparation for life.

\section{References}

i. African holocaust. (2014, February 28). Retrieved March 08, 2014, from African holocaustwebsite: www.africanholocaust.net

ii. Arthur, G. F. (2010 ). Centre For Indigenous Knowledge Systems. Retrieved March 8,2014, from CFIKS Web site:

iii. http://www.cfiks.org/cefiks/contactus.php

iv. Beattie, J. (1992). Other Cultures : Aims and Methods and Achievements in Social Anthroplology.Bodmin, Cornwall: Routledge.

v. Beidelman, T. O. (1971). The Kaguru: A Matrilineal People of East Africa. New York: Holt,Rinehart, and Wiston .

vi. Berry, E. (1984). Shakespeare's Comic Rites. Cambridge: Cambridge University Press.

vii. Brym, R. J., \& Lie, J. (2007). Sociology: Your Compass for a New World. Florence: Thomson Wadsworth.

viii. Crossman, A. (2014). Rites of Passage. Retrieved March 26, 2014, from Sociology:

ix. http:sociology.about.com/bio/Ashley-Crossman-38827.html

x. Frater, J. (2009, December 28). 10 Bizzare Rites of Passage. Retrieved March 31, 2014, from Listverse: http://www.listverse.com

xi. Gamst, F. C., \& Norbeck, E. (1976). Ideas of Culture: Sources and Uses. New York:Holt, Rinehart and Winston.

xii. Garrison, R. (1998). ReachingToday's Youth. Developmental Pathways as Rites of Passage Vol.3 , 33-38.

xiii. Grof, C. (1996). Crossroads, The Quest for Contemporary Rites of Passage. Illinois: Open Court.

xiv. Hart, C. W. (1967). Contrast between Pre-Pubertal and Post-Pubertal Education.New York: Random House.

xv. Heald, S. (2010, February 11). What does'Rite of Passage' mean? Retrieved April 23, 2014, from Rite of PassageArticle: http://www.myriteofpassage.com

xvi. Lott, T. (2014). Life and Style. Retrieved March 31, 2014, from Guardian Newa and Media: http://www.theguardian.com/lifeandstyle/series/man-about-the- house

xvii. McKay, K., \& Brett. (2008, November 09). Coming of Age: the Importance of Male Rite of Passage. Retrieved January 15, 2014, from artofmanliness: http://www.artofmanliness.com/about-2/

xviii. Myerhoff, B., Camino, L., \& Turner, E. (1987). The Encyclopedia of Religion- Rites ofPassage. New York:Macmillan.

xix. Nanda, S. (1987). Cultural Anthropology, 3rd Ed. Belmont,California: Wadsworth Publishing Company. Nanda, S., \& Warm, R. L. (2012). Culture Counts: A Concise Introduction to Cultural Anthrolopology. Belmont, California: Wadsworth.

xx. Norbeck, E. (2014). Rite of Passage. Retrieved March 23, 2014, from Encyclopædia Britannica, Inc.: http://www.britannica.com/bps/user-profile/2160/edward-norbeck

xxi. O'Neil, D. (2005). Characteristics of rites of passage. Retrieved April 23, 2014, from Palomar web site: http://anthro.palomar.edu/social/quizzes/socquiz4

xxii. Penner, H. H. (2014). Ritual. Retrieved April 23, 2014, from Britannica Incorporation:http://www.britannica.com Sanders , J. (2018). Leap of faith: Diving with the Vanuatu.Retrieved August 9, 2020, from https://medium.com/

xxiii. Schaefer, R. T., \& Lamm, R. P. (1995). Sociology. New York: MacGraw-Hill, Inc.

xxiv. Schultz, E. A., \& Lavender, R. H. (2005). Cultural Anthropology : A Perspective on Human Conditions, 6th Ed. Oxford: Oxford University Press.

xxv. Sisson, M. (2012, November 15). Do we Need Rites of Passag? Retrieved January 22, 2014, from Marks Daily

xxvi. Apple: http://www.marksdailyapple.com/ Sloshed, C. (2013, November 13). Rites of Passages outside U.S. Retrieved March 31,2014, from Sloshedspot: http://www.sloshedspot.com

xxvii. Stauber, R. J., \& Ronconi, L. (2013). Rights of Passage. Retrieved February 13, 2014,from PixelWorks: http://www.pixelworkscorporation.com/ 
xxviii. United Television, (2014, April 01). News Item. Accra, Greater Accra, Ghana.

xxix. Van Gennep, A. (1960). The Rites of Passage. Chicago: University of Chicago Press.

xxx. Wikipedia. (2014, September 30). Veneration of the dead. Retrieved October 02, 2014, from Wikipedia, the free encyclopedia: http://www.en.wikipedia.org 